УДК 159.923

DOI https://doi.org/10.32849/2663-5313/2020.3.58

Тетяна Матієнко,

канд. юрид. наук, дочент,

професор кафедри криміналістики та психології

Одеського державного університету внутрішніх справ

\title{
ГЕНДЕРНІ ОСОБЛИВОСТІ ПРОФЕСІЙНОГО РОЗВИТКУ ОСОБИСТОСТІ
}

У сучасному науковому знанні загальновизнаним є факт, що належність до певної статі є одним із значущих параметрів оцінки особистістю самої себе й оточуючих. Водночас професійний розвиток та становлення особистості як психологічний феномен у вітчизняній науці вивчались переважно без урахування гендерного чинника.

Активізація гендерних досліджень спостерігалася в середині минулого сторіччя значною мірою завдяки феміністському руху й обговоренню питань дискримінаиї жінок, зокрема, в професійній сфеpi. Становлення професійного образу Я, з одного боку, $є$ результатом дї багатьох взаємопов'язаних зовнішніх і внутрішніх чинників, у систему яких входить $і$ гендер. 3 іншого боку, вибір професіі i подальша професійна діяльність можуть впливати на гендерні ідентифікаційні моделі, гендерну ідентичність $i$, відповідно, на сочіальні моделі поведінки особистості.

Зростаючий інтерес до гендерних проблем має дуже глибоке коріння. 3 одного боку, відмінність чоловіків жінокє найфундаментальнішою відмінністю між індивідуумами, що належать до виду һото sapiens (як показали дослідження, саме ия відмінність перш за все фіксується і запам'ятовується людиною), з іншого боку, зараз йде проиес зміни і зближення гендерних ролей. Причому якщо раніше ия тендениія викликала й у психологів, і в суспільстві в цілому неспокій, то останніми роками ия тендениія розглядається як нормальна і позитивна.

Щодо гендерної ідентичності, то тут має місие усвідомлення свого зв'язку з культурними визначеннями мужності і жіночності.

Гендерні і статеві ідентичності, як правило, розкриваються через категорії «маскулінність» (мужність) $i$ «фемінність» (жіночність). Маскулінність і фемінність - статеспецифічні характеристики особистості, вони виступають як базові категорії під час аналізу гендерної ідентичності і психологічної статі. Поняття маскулінності і фемінності виражають нормативні уявлення й установки про те, якими повинні бути $i$, отже, чим повинні займатися чоловіки $і$ жінки в даному суспільстві і зараз. Маскулінність і фемінність є сочіальними, а не біологічними категоріями. Вони визначають нашу гендерну ідентичність і безпосередньо пов'язані з нашими уявленнями про себе та інших.

Ключові слова: гендерний чинник, ідентичність, «маскулінність»-(мужність), «фемінність»(жіночність).

Постановка проблеми. Суспільні трансформації, що відбуваються в нашій країні, сприяють підвищенню уваги до проблеми гендерних особливостей особистості. Актуальність соціально-психологічних досліджень гендерних особливостей професійного розвитку зумовлена, з одного боку, недостатнім рівнем розробки даної проблеми, зокрема, в Україні, де перші кроки в цьому напрямі були здійснені лише на початку 90-х років, з іншого боку - високими запитами практики на розробку даної наукової тематики.

У сучасному науковому знанні загальновизнаним $є$ факт, що належність до певної статі є одним зі значущих параметрів оцінки особистістю самої себе й оточення. Водночас професійний розвиток та становлення особистості як психологічний феномен у вітчизняній науці вивчались переважно без урахування гендерного чинника.

Стан розробленості проблеми. Проблема професійного розвитку особистості займає важливе місце в психологічних дослідженнях гендеру. При цьому найактуальнішим є пізнання взаємозв'язку професійного розвитку та психологічної статі майбутніх фахівців. Вітчизняні психологи, поряд із зарубіжними, зробили свій внесок у з'ясування особливостей професійного розвитку чоловіків і жінок. 
Так, Є. П. Ільїн розглядає це питання, виділяючи два взаємопов'язаних аспекти: адекватність самоставлення осіб різної статі й порівняння уявлень щодо власного «Я-образу» хлопців та дівчат. А. В. Візгіна, С. Р. Пантелєєв та М. Л. Кубишкіна розглядали особливості формування самооцінки залежно від професійної спрямованості чоловіків і жінок та вважали, що специфіка професійного самоставлення особистості залежить від соціальних умов життя людини.

Особливості самооцінки осіб різної статі різних вікових груп досліджувались I. Г. Герасимовою і О. М. Мороз. Зміни такого складника професійного самоставлення, як аутосимпатія, залежно від життєвого досвіду чоловіків та жінок були проаналізовані Ю. О. Кочнєвою і М. К. Омаровою. Різноманітні аспекти професійного розвитку хлопців і дівчат описувались також у працях В. М. Князєва, Н. М. Кирєєвої, В. Є. Каган. Проблема професійного розвитку вивчалась такими вченими, як В. В. Столін, О. Т. Соколова, І. І. Чеснокова, І. С. Кон, К. О. Абульханова-Славська, та іншими.

Мета і завдання дослідження - вивчення проблеми гендерних відмінностей у професійному розвитку особистості у зв'язку з їх міжстатевою взаємодією.

Виклад основного матеріалу. Вивчення психологічних проблем, що виникають у системі «професія-гендер», було основане на дослідженнях статевих відмінностей і визначенні значущості біологічної статі стосовно вербальних, математичних i просторово-зорових здібностей. Активізація гендерних досліджень спостерігалася в середині минулого сторіччя значною мірою завдяки феміністському руху й обговоренню питань дискримінації жінок, зокрема, в професійній сфері. Становлення професійного образу Я, з одного боку, є результатом дії багатьох взаємопов'язаних зовнішніх і внутрішніх чинників, в систему яких входить і гендер. 3 іншого боку, вибір професії і подальша професійна діяльність можуть впливати на гендерні ідентифікаційні моделі, гендерну ідентичність i, відповідно, на соціальні моделі поведінки особистості [5, с. 232].

Дослідження гендерних характеристик особистості пов'язане 3 концептуальними і методологічними труднощами. Сам термін «гендер» вказує на відмінності між чоловіками і жінками, створені культурою, проте причинно-наслідковий зв'язок між ними не завжди очевидний і може бути зумовлений як психологічними, так і соціальними чинниками.
Зростаючий інтерес до гендерних проблем має дуже глибоке коріння. 3 одного боку, відмінність чоловіків і жінок є найфундаментальнішою відмінністю між індивідуумами, що належать до виду homo sapiens (як показали дослідження, саме ця відмінність перш за все фіксується і запам'ятовується людиною), з іншого боку, зараз йде процес зміни і зближення гендерних ролей. Зазвичай більшу увагу приділяють зміні гендерних ролей жінок, які все частіше реалізують себе в традиційно чоловічих сферах соціальної активності (політика, бізнес, армія, «чоловічі» види спорту), хоча одночасно йде не менш, на мою думку, важливий процес зміни гендерних ролей чоловіків, які все частіше беруть участь у традиційно жіночих сферах соціальної активності (виховання дітей, домашнє господарство). Крім того, спостерігається тенденція андрогінії - прояву у жінок «чоловічих» рис вдачі, а у чоловіків - «жіночих». Причому якщо раніше ця тенденція викликала і у психологів, і в суспільстві в цілому неспокій, то останніми роками ця тенденція розглядається як нормальна і позитивна. Згідно з Карлом Густавом Юнгом, у чоловіка є аніма - несвідомий жіночий бік особистості чоловіка, а у жінки анімус - несвідомий чоловічий бік особистості жінки. Юнг пише: «Молоді люди можуть пережити повну втрату аніми без жодного збитку. На цій стадії головне - бути чоловіком. < ..> Після середини життя втрата аніми веде до зниження життєвості, гнучкості, рухливості, доброти - з'являється ригідність, сварливість, стереотипність, фанатизм, упертість, педантичність і водночас покірливість, стомлюваність, неохайність, безвідповідальність i, зрештою, дитяча дратівливість зі схильністю до алкоголю» [3, с. 67].

Водночас «гендерна роль, - зазначає В. В. Москаленко, - моделює комбінацію рис чоловіка і жінки, формує гендерні якості індивіда, розкриває в певному напрямі його здібності, спрямовує на здійснення тих чи інших видів діяльності». Отже, засвоєння людиною тієї чи іншої гендерної ролі детермінує всі інші її особистісні якості.

Нині у чоловічому світі жінкам, щоб досягти успіху у сферах, що найбільшою мірою визначають сучасний розвиток суспільства (політика, бізнес, управління в цивільній і військовій сфері), доводиться відмовлятися від свого біологічного жіночого начала і грати за чоловічими правилами. При цьому, відповідно до статево-рольових стереотипів, добротне виконання завдання, високий результат, досягнутий чоловіком найчастіше пояснюється його здібностями (стабільні причини), а такий саме результат, досягнутий жінкою, пояснюється її зусиллями, 
випадковою удачею чи іншими нестабільними причинами. Більш того, сама типологія стабільних і нестабільних причин виявляється неоднаково, залежно від того, чия поведінка пояснюється - чоловіка чи жінки. Встановлено також, що і «здатності», i «зусилля» можуть мати різні оцінки коннотації у поясненні поведінки жінок і чоловіків. Так, наприклад, у разі пояснення успіху жінки фактор зусиль розглядається найчастіше як нестабільний і загалом має певне негативне оцінне забарвлення, а стосовно професійних успіхів чоловіка цей фактор інтерпретується як стабільний і такий, що має позитивну оцінну валентність як необхідну умову «природної чоловічої потреби в досягненні», як засіб подолання бар'єрів і труднощів, що постають на шляху до мети. У реальній міжособистісній взаємодії й у особистісному плані компетентність виявляється для жінок швидше негативним, ніж позитивним фактором: жінки 3 високою компетентністю не користуються прихильністю ні чоловіків, ні жінок [2, с. 78].

Щодо гендерної ідентичності, то тут має місце усвідомлення свого зв'язку з культурними визначеннями мужності і жіночності. Це поняття охоплює суб'єктивний досвід і є психологічною інтеріоризацією чоловічих і жіночих рис у процесі взаємодії «Я та інші». Гендерна ідентичність тісно пов'язана з уявленням про свою стать: чи відчуває себе людина чоловіком або жінкою.

Чоловіча ідентичність - зарахування себе до категорії чоловічої соціальної групи і відтворення відповідних гендерно-зумовлених ролей і самопрезентаций. В основі конструювання чоловічої ідентичності лежить «ідеологія мужності» (J. H. Pleck), «принцип Адама», або принцип «маскулінної додатковості» (Дж. Ман). Чоловіча ідентичність безпосередньо пов'язана з культурною нормою антижіночності, традиційна чоловіча гендерна роль $€$ причиною тривоги і напруги (Ш. Бурн) [4, с. 47].

Жіноча ідентичність - зарахування себе до категорії жіночої соціальної групи і відтворення відповідних гендерно-зумовлених ролей і самопрезентаций. Конструювання жіночої ідентичності безпосередньо пов'язують зі специфічним «жіночим досвідом». Слід зазначити, що менша цінність «жіночого» в суспільстві утруднює розвиток позитивної Я-концепції дівчинки, породжує проблеми створення жіночої ідентичності, особливо якщо дівчинка володіє високими соціальними здібностями і схильна лідирувати. В уявленнях про гендерну ідентичність можна виділити 4 етапи (хоча цей термін з'явився тільки в 1970-х рр., раніше існували його аналоги: статева, або стате-ролева іден- тифікація, ототожнення себе з певною статтю і т. ін.). Розглянемо їх детальніше [2, с. 79].

Перший, дофройдівський, етап - початок XX ст. У ранніх дослідженнях, присвячених психології жінки (Р. Гейманс, П. Е. Астафьев та ін.), відбивалося наївне життєве уявлення про те, що жінка повинна відповідати якомусь ідеалу (сформованому у вищому суспільстві): бути емоційною, загадковою, млосною, слабкою, дбайливою, хорошою матір'ю - тобто жіночною (i в поведінці, і в одязі, і в зачісці, і в заняттях). Тi, хто відхилявся від цього ідеалу, піддавалися засудженню і остракізму.

Другий етап, пов'язаний 3 діяльністю 3. Фрейда і його послідовників, охоплюе період з 1920-х по 1970-і рр. У своїй роботі «Жіночність» (цю назву можна вважати символічною) Фрейд зобразив жінок такими, що заздрять чоловічій анатомії (так званий комплекс кастрації), і зробив висновок, що «фемінними» рисами є пасивність, залежність і схильність до підкорення. Чоловіків же він вважав активними і прагнучими до влади. Будь-яке відхилення від цих еталонів вважалося проявом хворої гендерної ідентичності. Зокрема, прагнення жінок до влади (характеристика, яка повинна бути у чоловіка) було назване фалічним (Фрейд, 1991) [6, с. 260].

Третій етап - 70-80-і pp. ХХ ст. Цей етап пов'язаний $з$ іменами двох жінок - Сандри Бем і Джудіт Спенс. Для пояснення різних варіацій гендерної ідентичності вони звернулися до ідеї андрогінії. У 1974 р. Сандра Бем сформулювала свою гіпотезу про існування 3-х типів людей 3 різною гендерною ідентичністю: $з$ переважанням фемінних характеристик, з переважанням маскулінних характеристик і «андрогінних», тобто тих, у кого спостерігається баланс маскулінних і фемінних характеристик. При цьому найпривабливішим їй здавався третій тип: на її думку, андрогінні особистості володіють адаптивністю і гнучкістю поведінки, відрізняються творчими схильностями і найбільш психологічно благополучні. Перші ж два типи зображалися негнучкими, обмеженими, такими, що демонструють у своїй поведінці гендерні стереотипи, що існують у суспільстві.

У 1975 р. Джудіт Спенс піддала критиці операціональне визначення андрогінії, зроблене Бем, і запропонувала інший показник: андрогінність - це поєднання високої маскулінності й високої фемінності. Це абсолютно інше розуміння андрогінії. Представимо, наприклад, таке поєднання протилежних характеристик, як домінантність і підлеглість, асертивність і поступливість - в принципі, це поєднання можливе, але свідчить швидше 
не про збалансованість і гармонійність особистості, а про іï суперечність і амбівалентність. Поєднуватися можуть не протилежні якості, а якості, що характеризують різні особливості особистості, наприклад владність і ніжність, відданість і дух змагання. Але і ці поєднання свідчать про деяку амбівалентність. Зрозуміло, що в такому розумінні андрогінні суб́'єкти справляли враження людей із хворою гендерною ідентичністю. Щоправда, сама Спенс так не вважала навпаки, андрогінність асоціювалася для неї з високою самооцінкою і психічним благополуччям людини. Загалом нею було виділено 4 типи людей: типові чоловіки, типові жінки, андрогінні особистості і недиференційовані особистості з низькими показниками маскулінності і фемінності [2, с. 80].

Ідея андрогінії на декілька років викликала натхнення у зарубіжних дослідників. Вона почала використовуватися в різних прикладних галузях психології. Так, теорія андрогінного менеджменту А. Сарджента, наприклад, стверджувала, що ефективний лідер повинен переймати краще, що є в якостях іншої статі, й інтегрувати чоловічі і жіночі характеристики. Четвертий етап охоплює останні декілька років. Після натхнення настало розчарування. Сама Сандра Бем відмовилася від ідеї андрогінії, оскільки в суспільстві, в якому дуже популярне чітке розділення на «чоловіче-жіноче», виховувати дітей у дусі невизначеної й не дуже зрозумілої андрогінності - означає ставити їх в складні умови [7, с. 92].

Останнім часом почали розвиватися кроскультурні дослідження гендерної ідеології. Цікавий матеріал у цьому плані міститься в книзі Н. М. Лебедєвої (1999). Були досліджені уявлення про те, які якості є бажаними для чоловіків і які - для жінок, в 14 культурах. 3'ясувалося, що в розвинених країнах популярна ідея егалітарності (рівність статей), а в традиційних культурах (особливо мусульманських - Індії, Пакистані, Нігерії) - ідея переваги відмінностей між чоловіками і жінками.

Гендерні і статеві ідентичності, як правило, розкриваються через категорії «маскулінність» (мужність) і «фемінність» (жіночність). Маскулінність і фемінність - специфічні характеристики особистості, вони виступають як базові категорії під час аналізу гендерної ідентичності і психологічної статі. Поняття маскулінності і фемінності виражають нормативні уявлення й установки про те, якими повинні бути i, отже, чим повинні займатися чоловіки і жінки в даному суспільстві і зараз. Маскулінність і фемінність є соціальними, а не біологічними категоріями. Вони визначають нашу гендерну ідентичність і безпосередньо пов'язані з нашими уявленнями про себе та інших.

Виділяють три різних значення поняття «маскулінність» - «фемінність».

1. Маскулінність/фемінність як дескриптивна, описова категорія, означає сукупність поведінкових і психологічних рис, властивостей і здібностей, об'єктивно властивих чоловікам/жінкам.

2. Маскулінність/фемінність як аскриптивна категорія позначає один з елементів символічної культури суспільства, сукупність соціальних уявлень, установок і вірувань про те, чим чоловік/жінка є, які якості їм приписуються.

3. Маскулінність/фемінність як прескриптивна категорія - це система приписів, що мають на увазі не середньостатистичного, а ідеального «справжнього» чоловіка/жінку, це нормативний еталон мужності/жіночності.

Розглядаючи маскулінність, у дослідженнях враховують іiі множинність, історичність і ситуаційність. Множинність виявляється в наявності в кожному суспільстві множинності моделей маскулінності від домінантних до маргіналізованих. Домінантна модель маскулінності відображає уявлення про чоловічу гендерну роль, що поділяються домінуючою (за расовими, соціальними і культурними ознаками) частиною суспільства. Історичність маскулінності відображають зміни їі структури в ході історичних процесів. Ситуаційність маскулінності виявляється через соціокультурну залежність інтенсифікаційних та інфляційних змін, що відбуваються 3 деякими її характеристиками [1, с. 45].

Образ «Я - чоловік» у чоловіків і «Я - жінка» у жінок розуміється як частина самосвідомості особистості, усвідомлення себе як представника певної статі, ставлення до цього процесу, надбання певних форм поведінки, навиків, стереотипів у процесі соціалізації. Постулюється ідея про те, що образ «Я - чоловік» у чоловіків, «Я - жінка» у жінок є основоположним у формуванні особистості, оскільки починає своє становлення раніше за інші складники її самосвідомості, впливаючи на формування інших складників і образів Я. Тобто образ «Я - чоловік або «Я - жінка» може впливати як на становлення особистості загалом, так і на становлення професійного образу «Я» зокрема.

У контексті гендерної психології аналізуються особливості гендерного образу «Я». Виявлено, що гендерна самосвідомість особистості формується на ранніх етапах 
соціалізації особи і визначає особливості формування інших образів «Я», наприклад професійного образу «Я», який також $€$ найважливішим упродовж більшої частини активного соціального життя особистості. Професійний образ «Я»- це усвідомлення і оцінка себе як представника певної професії. Чинниками, що впливають на зміну гендерного і професійного образів «Я», є вік, фаза життя, сам етап і зміст професійного становлення та ін. У процесі становлення професійного образу «Я» відбуваються істотні зміни самосвідомості особи, які примушують людину переживати різні негативні стани, що впливають на суб'єктивне благополуччя особистості і знижують рівень самоактуалізації [1, с. 45].

Гендерні дослідження в психології підтверджують, що соціально-психологічна стать особистості $€$ найважливішим чинником, що впливає на розвиток професійного образу «Я». Дослідники виділяють різні аспекти взаємодії гендерної і професійної ідентичності у представників різних професійних, вікових, соціальних і етнічних груп. Більшість авторів відзначають, що досягнення взаємозв'язку гендерної і професійної ідентичності - це складний і поетапний процес, що включає взаємодію різних компонентів, змістовних характеристик i властивостей особистості. Причому істотніші переживання припадають на долю жінок, оскільки в більшості європейських і західних країн до цих пір збереглися гендерні стереотипи і установки стосовно жінок (Т. В. Бендас, Ш. Берн, І. С. Клеціна, В. А. Лабунська і ін.). Дослідники виділяють різні суперечності в самосвідомості особистості між образами «Я - жінка», «Я - професіонал», «Я - мати», «Я - господиня» і так далі (Е. Ю. Альошина, О. Арнольд, А. Н. Кімберг, І. С. Кон, А. Л. Фестінгер, Г. Шихи й ін.) [8, с. 233].

Отже, у сфері зайнятості існує асиметричне розміщення чоловіків і жінок у професійній структурі: ряд професій $є$ практично або чоловічими, або жіночими. Соціальні психологи Г. Гібш і М. Форверг, спираючись на погляди А. А. Гольденвейзера, бачать причину цього не в біологічних особливостях чоловіків і жінок, а в соціальних умовах, що складаються в тому або іншому суспільстві. Соціальні чинники впливають на вибір жінками і чоловіками тієї або іншої професійної діяльності, і практика показує, що хоча жінки неохоче освоюють сфери діяльності, де переважають чоловіки, побоюючись, що їх вважатимуть менш жіночними, проте цей чинник останніми роками все більше втрачає свою значущість. За даними Л. Термана і К. Майлза, жінки, що зробили кар'єру, в середньому виявилися більш мас- кулінними, ніж жінки, які не досягли певних результатів. За даними Е. Таслер, серед жінок, що характеризуються прагненням до конкуренції, боротьби, подолання перешкод, співвідношення гендерних типів було таким: фемінних - $43 \%$, маскулінних - $30 \%$, андрогінних - $27 \%$ (дослідження за методикою С. Бем) $[1$, с. 49].

Результати досліджень показали певні відмінності між юнаками і дівчатами в процесі професійного самовизначення, а також подальшого становлення професійного образу «Я», в їхніх динамічних і особистісних характеристиках: С. Сінгер, Б. Штефлер, I. Н. Вакулова, С. П. Крягжде, Д. П. Барама, Л. А. Головей, Б. Розен, доходять висновку, що більшість підлітків вибирають професії, відповідні їхній гендерній ідентичності, в професійному самовизначенні дівчата займають активнішу позицію щодо вибору професії, усвідомленості і визначеності шляхів її отримання (Ю. П. Вавілова і Н. В. Андрєєнкова, Л. А. Головей). Професійне самовизначення у юнаків формується в руслі загальної життєвої перспективи й органічно входить у нього. На їхнє професійне самовизначення впливають чинники перспективи: чим більш визначені плани на подальше життя, тим вищий рівень сформованості професійного образу «Я» і ступінь упевненості в правильності професійного вибору. У дівчат життєве і професійне самовизначення менше пов'язані між собою, для них характерна велика емоційність і ситуативність самовизначення [9, с. 191].

\section{Висновки}

Таким чином, гендерна ідентичність, будучи однією з базових структур самосвідомості, відіграє важливу роль у процесах побудови життєвого плану, самовизначення, формування образу майбутнього. Гендерна ідентичність, яка збігається 3 біологічною і психологічною статтю особистості, сприяе успішному самовизначенню, зокрема професійному, а також і подальшому становленню професійного образу «Я». Розмита гендерна ідентичність, низька диференційованість статевих еталонів знижує вплив гендерної ідентифікації як механізму, що впливає на вибір цінностей, становлення професійного образу «Я» та ставлення до себе як до професіонала.

\section{Список використаних джерел:}

1. Васильєв I.A., Магомед-Емінов М.Ш Мотивація і контроль за дією Москва : Вид. МДУ, $1991.280 \mathrm{c}$.

2. Вилюнас, В.К. Психологічні механізми мотивації людини. Москва : Изд-во Моск. ун-та, 1990. 288 c. 
3. Гендерна педагогіка. Хрестоматія / пер. $з$ англ. А. Предборської ; за ред. В. Гайденко. Суми: ВТД «Університетська книга». 2006. 313 с.

4. Климов Е.А. Психология профессионального самоопределения. Ростов-на-Дону : Феникс 1996. $304 \mathrm{c}$.

5. Музика О.Л. Ціннісна підтримка особистісного росту. Науковий часопис НПу імені М.П. Драгоманова. Серія «Психологічні науки»: зб. наукових праць. Київ : НПУ імені М.П. Драгоманова, 2005. № 6 (30). Ч. II. С. 232-240.

6. Помиткіна Л. В. Розвиток особистісної готовності студентів до прийняття стратегічного життєвого рішення з професійного самовизначення. Науковий вісник Миколаївського державного універ- ситету імені В. О. Сухомлинського. Серія «Психологічні науки». 2013. Т. 2. Вип. 10. С. 258-262.

7. Приходько Е.М. Динамика формирования профессионально важных качеств будущих юристов в системе высшего профессионального образования. Интегращия образования. 2014. Т. 18. № 4 (77). C. 91-97.

8. Старовойт Т. П. Гендерні чинники мотивації навчально-професійної діяльності студентів. Вісник Харківського начіонального педагогічного університету імені Г. С. Сковороди. Серія «Психологія». 2015. Вип. 50. С. 232-238.

9. Шведова Я. В. Умови професійного розвитку особистості студента. Наукові записки кафедри педагогіки. 2012. Вип. 30. С. 190-195.

In modern scientific knowledge, it is universally accepted that belonging to a particular gender is one of the significant parameters of self-esteem and others. At the same time, professional development and personality development, as a psychological phenomenon, in the national science have been studied mainly without taking the gender factor into the considerstion.

The intensification of gender studies has been observed in the middle of the last century, largely due to the feminist movement and the discussion of discrimination against women, particularly in the professional field. Formation of a professional I-image, on the one hand, is the result of many interrelated external and internal factors, which includes gender. On the other hand, choice of profession and further professional activity can influence gender identity models, gender identity and social behavior patterns.

The growing interest in gender issues is deeply rooted. On the one hand, the difference between men and women is the most fundamental difference between individuals belonging to the homo sapiens species (research has shown that this difference is first and foremost recorded and remembered by a human being); on the other hand the gender roles are changing and becoming more alike. Moreover, previously this tendency has caused anxiety among both psychologists and society, though nowadays this tendency is considered as normal and positive.

Gender and gender identities are generally revealed through the categories of masculinity (masculinity) and femininity (femininity). Masculinity and femininity are gender-specific characteristics of personality, they act as basic categories in the analysis of gender identity and psychological gender. The notions of masculinity and femininity express the normative ideas and attitudes that should be and, therefore, what men and women should do in this society today. Masculinity and femininity are rather social than biological categories. They define our gender identity and are directly related to our perceptions of ourselves and others.

Key words: gender, identity, "masculinity", "femininity". 